\title{
PEMBUATAN TRAINER TROUBLESHOOTING INSTALASI PENERANGAN LISTRIK SEBAGAI MEDIA PEMBELAJARAN PADA MATA PELAJARAN INSTALASI PENERANGAN LISTRIK KELAS XI DI SMK NEGERI 5 JAKARTA
}

\author{
Henny Herdianti ${ }^{1}$, Soeprijanto $^{2}$, Purwanto Gendroyono ${ }^{3}$ \\ ${ }^{1,2,3}$ PendidikanTeknik Elektro, Fakultas Teknik, Universitas Negeri Jakarta \\ ${ }^{1}$ E-mail :henny.herdianti@gmail.com
}

\begin{abstract}
The purpose of this research is to make the design of an trainer Troubleshooting Instalasi Penerangan Listrik on the subjects of Electrical Lighting Installation for students of class XI. The method used is a method of research and development $(R \& D)$ with reference to instructional media development method proposed by Sadiman (1990). The process of collecting data through testing and observation of product trainer as well as a questionnaire study then analyzed by qualitative descriptive technique.

The results of this research are the product trainer who has tested the feasibility as a media of learning. The results of the feasibility trainer, namely (1) Testing by subject matter experts expressed good or feasible with the acquisition percentage of feasibility worth of $72 \%$, (2) Testing by media experts expressed very good or very feasible with the acquisition of the percentage of feasibility worth of $89.6 \%$, and (3) Testing by the user in the form of two teachers expressed very good or very feasible with the acquisition of the percentage of feasibility worth of $93.2 \%$ and 30 students expressed a good or feasible with the acquisition of the percentage of feasibility worth of $82.32 \%$.

From the results of this research concluded that the trainer Troubleshooting Instalasi Penerangan Listrik can be used as a media of learning in subjects Electrical Lighting Installation class XI at SMK Negeri 5 Jakarta

Keywords: Trainer, Troubleshooting Instalasi Penerangan Listrik, Media of Learning
\end{abstract}

\begin{abstract}
Abstrak
Tujuan penelitian ini yaitu membuat desain sebuah trainer Troubleshooting Instalasi Penerangan listrik pada mata pelajaran Instalasi Penerangan Listrik untuk siswa kelas XI. Metode penelitian yang digunakan adalah metode penelitian dan pengembangan (Research \& Development) dengan mengacu pada metode pengembangan media pembelajaran yang diajukan oleh Sadiman (1990). Proses pengumpulan data yaitu melalui pengujian dan pengamatan produk trainer serta angket penelitian yang kemudian dianalisis dengan teknik deskriptif kualitatif.

Hasil penelitian ini adalah produk trainer yang telah diuji tingkat kelayakannya sebagai media pembelajaran. Kelayakan trainer berdasarkan hasil uji kelayakan, yaitu (1) Pengujian oleh ahli materi dinyatakan baik atau layak dengan perolehan persentase kelayakan senilai $72 \%$, (2) Pengujian oleh ahli media dinyatakan sangat baik atau sangat layak dengan perolehan persentase kelayakan senilai 89,6\%, dan (3) Pengujian oleh pengguna berupa 2 orang guru dinyatakan sangat baik atau sangat layak dengan perolehan persentase kelayakan senilai 93,2\% dan 30 siswa dinyatakan baik atau layak dengan perolehan persentase kelayakan senilai $82,32 \%$.

Dari hasil penelitian dapat disimpulkan bahwa trainer Troubleshooting Instalasi Penerangan Listrik dapat digunakan sebagai media pembelajaran pada mata pelajaran Instalasi Penerangan Listrik kelas XI di SMK Negeri 5 Jakarta.

Kata Kunci: Trainer, Troubleshooting Instalasi Penerangan Listrik, Media Pembelajaran
\end{abstract}

\section{PENDAHULUAN}

SMK merupakan pendidikan kejuruan formal di Indonesia yang bertujuan mempersiapkan siswa atau peserta didiknya untuk dapat bekerja di bidang tertentu, hal ini tertuang dalam Undang-undang RI No. 20 Tahun 2003. Keberhasilan lulusan SMK yang memiliki kompetensi unggul dapat dipengaruhi oleh beberapa faktor, salah satunya adalah mutu pengajaran. Upaya yang dilakukan agar lulusan
SMK dapat bersaing di dunia kerja yaitu memberikan pembelajaran yang lebih menekankan kepada keterampilan atau praktek dibandingkan dengan teori.

Untuk mendukung kegiatan belajar tersebut, maka sangat diperlukan suatu media pembelajaran. Media pembelajaran yang diperlukan sekolah kejuruan harus memiliki bentuk atau kondisi yang mirip dengan dunia 
nyata di masyarakat atau keadaan di lapangan kerja contohnya berupa alat peraga atau trainer. Penggunaan alat peraga atau trainer tersebut dapat memudahkan guru atau pendidik menyajikan pembelajaran kepada siswa dengan memberikan model tampilan yang sesuai keadaan sesungguhnya yang berbentuk replika atau benda asli yang disederhanakan sehingga pembelajaran dapat dilakukan di dalam kelas.

Berdasarkan pengamatan di SMK Negeri 5 Jakarta yang berada di wilayah Jakarta Timur, peneliti menemukan permasalahan dalam proses kegiatan belajar di kelas XI pada mata pelajaran Instalasi Penerangan Listrik. Dalam kegiatan praktikum tersebut, media yang tersedia belum sepenuhnya lengkap sehingga berpotensi ketidakoptimalan belajar. Media untuk melakukan pemeriksaan dalam hal mencari kesalahan atau gangguan yang ada pada instalasi penerangan listrik belum dilaksanakan pada kegiatan praktikum, pembelajaran materi tersebut sebatas teorinya saja karena belum tersedia media pembelajaran yang mendukung.

Pada silabus mata pelajaran tersebut terdapat kompetensi dasar tentang "Memeriksa instalasi lampu penerangan pada bangunan gedung". Materi pemeriksaan instalasi penerangan listrik itu perlu dipahami oleh siswa karena mengingat kebutuhan energi listrik yang sangat penting untuk kegiatan sehari-hari, sehingga harus terjamin kontinuitas operasinya. Selain itu berbagai macam gangguan pada instalasi penerangan listrik juga perlu ditangani karena dapat menimbulkan bahaya mulai dari kejut listrik hingga kebakaran akibat listrik, contohnya yang sering terjadi di masyarakat seperti gangguan hubung singkat, beban lebih, kesalahan penggunaan dan pemasangan komponen listrik, pemakaian penghantar tanah, kerusakan perangkat elektronik, dan sebagainya.

Mengingat betapa pentingnya materi pemeriksaan instalasi penerangan listrik tersebut, maka peneliti bermaksud untuk membuat suatu media pembelajaran yang membantu kegiatan belajar terutama kegiatan keterampilan psikomotor. Media pembelajaran yang dimaksud berupa alat peraga atau trainer yang dapat mensimulasikan keadaan kesalahan atau gangguan pada sistem instalasi penerangan listrik yang selanjutnya harus mencari sumber masalahnya, sehingga dapat diselesaikan permasalahan tersebut, istilah lainnya disebut dengan troubleshooting. Jadi dengan adanya trainer tersebut, siswa dapat melakukan troubleshooting terhadap sistem instalasi penerangan listrik dan pelaksanaannya dapat dilakukan di dalam kelas sebagai kegiatan praktikum.

\section{METODE}

Pada penelitian ini akan menghasilkan suatu produk berupa alat trainer dan diuji kelayakan dari produk tersebut sebagai media pembelajaran, sehingga metode yang digunakan adalah metode penelitian dan pengembangan atau biasa disebut dengan Research and Development. Menurut Sugiyono, Metode penelitian dan pengembangan atau dalam bahasa Inggrisnya Research and Development adalah metode penelitian yang digunakan untuk menghasilkan produk tertentu dan menguji keefektifan produk tersebut (Sugiyono, 2009:297). Adapun langkah-langkah yang akan dilakukan pada pembuatan alat trainer dalam penelitian ini, mengacu kepada metode pengembangan media pembelajaran yang diajukan oleh Sadiman (1990) yaitu sebagai berikut:

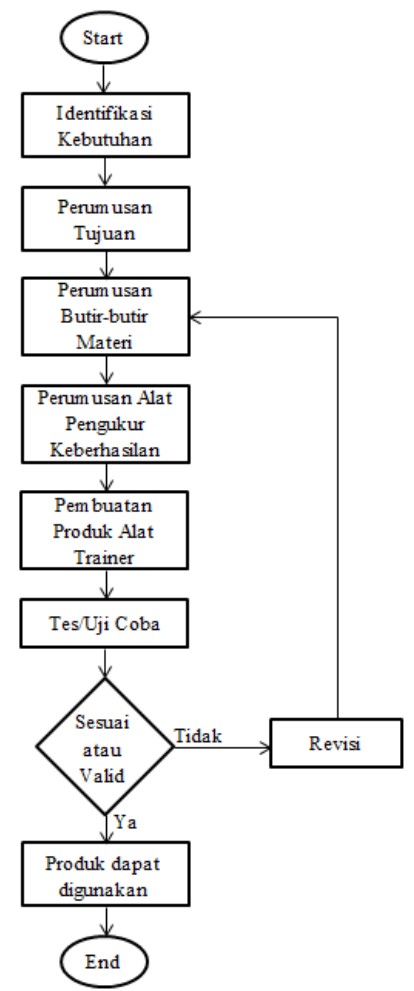

Gambar 1. Flowchart Pembuatan Trainer 


\section{HASIL DAN PEMBAHASAN \\ Identifikasi Kebutuhan}

Berdasarkan pengamatan di SMKN 5 Jakarta ditemukan bahwa pada proses kegiatan belajar di mata pelajaran Instalasi Penerangan Listrik kelas XI menunjukkan kurang optimal, dikarenakan kurang tersedianya media pembelajaran untuk salah satu materi yaitu troubleshooting instalasi penerangan listrik. Troubleshooting merupakan pencarian sumber masalah secara sistematis yang selanjutnya masalah tersebut dicarikan solusinya. Dengan kata lain troubleshooting dalam instalasi penerangan listrik berarti mencari sumber masalah yang terjadi pada sistem instalasi penerangan listrik karena sesuatu gangguan atau kesalahan di dalamnya sehingga sistem instalasi penerangan listrik tidak berjalan dengan baik dan selanjutnya mencari solusi agar sistem tersebut dapat kembali normal.

Dalam proses kegiatan belajar dikelas mengenai materi tersebut, siswa baru sebatas diberikan pemahaman melalui ceramah dan belajar dari modul yang disiapkan oleh guru (secara teori). Mengingat pentingnya memahami gangguan instalasi penerangan listrik yang sering terjadi di masyarakat yang akan mengakibatkan kerugian seperti bahaya kejut listrik hingga kebakaran dan pentingnya memahami penggunaan alat ukur dalam memeriksa gangguan tersebut, maka pada mata pelajaran ini perlu diimbangi dengan kegiatan praktikum yang memberikan kesempatan siswa untuk mengimplikasikan teori yang didapat dalam kelas. Oleh karena itu, dibutuhkan media penunjang dalam pembelajaran praktikum untuk mata pelajaran instalasi penerangan listrik kelas XI, pada kompetensi dasar dari memeriksa instalasi lampu penerangan pada bangunan gedung berupa alat trainer troubleshooting instalasi penerangan listrik yang dapat mensimulasikan berbagai macam gangguan.

\section{Perumusan Tujuan}

Dari analisis kebutuhan tersebut, maka selanjutnya menentukan tujuan yang ingin dicapai. Pada pembuatan alat trainer troubleshooting instalasi penerangan listrik ini memiliki tujuan yang memfokuskan kepada pencapaian pemahaman dan keterampilan siswa. Sehingga diharapkan dengan media pembelajaran berupa alat trainer tersebut, siswa dapat memahami sistem instalasi penerangan listrik dalam keadaan normal atau beroperasi dengan baik; siswa dapat menganalisis gangguan atau kesalahan yang menjadi sumber masalah pada sistem instalasi penerangan listrik; dan kemudian siswa dapat memecahkan permasalahan atas sumber masalah tersebut.

\section{Perumusan Butir-butir Materi}

Setelah tujuan telah ditetapkan, maka selanjutnya adalah mengembangkan atau merumuskan butir-butir materi yang sesuai dengan tujuan. Materi troubleshooting masuk kedalam kompetensi dasar "Memeriksa instalasi lampu penerangan pada bangunan gedung". Materi tersebut dapat diberikan pada kegiatan belajar mengajar di dalam kelas. Kemudian siswa mengimplementasikan teori tersebut pada kegiatan praktikum dengan menggunakan trainer troubleshooting instalasi penerangan listrik. Karena adanya keterbatasan untuk dapat memberikan simulasi berbagai macam gangguan instalasi penerangan listrik yang ada, maka hanya diberikan tiga macam gangguan yang biasa sering terjadi di masyarakat, yaitu berupa gangguan terhadap kawat penghantar/kabel, gangguan terhadap beban lebih, dan gangguan terhadap komponen-komponen instalasi penerangan listrik.

Dengan demikian, rumusan butir-butir materi diuraikan kedalam indikator pembelajaran, yaitu sebagai berikut:

1. Mendiagnosis sistem instalasi penerangan listrik rumah sederhana terhadap gangguan sambungan penghantar.

2. Menganalisis sistem instalasi penerangan listrik rumah sederhana terhadap gangguan beban lebih.

3. Mendiagnosis sistem instalasi penerangan listrik rumah sederhana terhadap gangguan kesalahan peralatan komponen listrik.

\section{Perumusan Alat Pengukur Keberhasilan}

Langkah selanjutnya setelah perumusan butirbutir materi pembelajaran yaitu perumusan alat pengukur keberhasilan. Dalam perumusan alat pengukur keberhasilan harus sesuai dengan 
tujuan yang telah ditetapkan. Alat pengukur keberhasilan dapat dikatakan juga sebagai bahan evaluasi terhadap kegiatan praktikum siswa.

Aspek penilaian berupa persiapan kerja, proses, hasil kerja, sikap kerja, dan waktu penyelesaian yang diamati oleh guru atau instruktur pada proses kegiatan praktikum berlangsung dengan menggunakan trainer troubleshooting instalasi penerangan listrik.

\section{Pembuatan Produk Alat Trainer}

Perencanaan konstruksi alat trainer berbentuk balok dengan ukuran panjang $120 \mathrm{~cm}$, lebar 25 $\mathrm{cm}$, dan tinggi $80 \mathrm{~cm}$. Pada badan alat terbuat dari bahan papan akrilik berwarna putih kapur untuk bagian depan, sedangkan bagian atas, bawah dan samping menggunakan papan tripleks milamin, serta dilapisi alumunium siku $2 \mathrm{~cm}$ pada sisi kanan, kiri, bawah, dan atas papan dan juga dilengkapi dengan 4 buah kaki roda di bawah alat trainer agar mempermudah saat di pindahkan. Untuk bagian belakang ditutupi oleh dua buah papan tripleks yang dapat digeser ke kanan dan kiri agar mudah dibuka tutup.

Trainer ini mensimulasikan tiga bentuk gangguan yang paling sering terjadi di masyarakat. Pertama yaitu gangguan pada sambungan penghantar/kabel instalasi listrik. Simulasi gangguan atau kesalahan pada instalasi listrik tersebut dapat dilakukan dengan memberikan sakelar di beberapa tempat pada kawat penghantar/kabel dalam pengawatan instalasi penerangan listrik. Terdapat 48 buah sakelar pengendali pada trainer yang selanjutnya disebut sakelar simulasi dalam penulisan ini.

Sistem instalasi penerangan listrik akan berfungsi dengan baik atau keadaan normal apabila semua sakelar simulasi dalam keadaan NC (normally close) atau tersambung. Selanjutnya guru memberikan simulasi kesalahan yang nantinya siswa akan melakukan troubleshooting menggunakan ohmmeter dan voltmeter pada bagian komponen dan penghantar yang sudah dipasang banana jack. Jika sudah menemukan gangguan tersebut maka dicari solusinya agar dapat bekerja normal kembali.

Gangguan kedua yaitu mensimulasikan beban lebih. Pada sistem instalasi listrik tersebut, semua komponen seperti lampu dinyalakan atau diaktifkan dan seluruh stop kontak diberi beban dengan beban yang melebihi nilai arus listrik yang terpasang pada pengaman arus/MCB. Dengan demikian, siswa dapat menganalisis masalah tersebut dengan menghitung kebutuhan beban yang terpakai. Selanjutnya mencari solusi dari masalah tersebut.

Sedangkan gangguan yang ketiga yaitu mensimulasikan pemasangan komponen peralatan listrik yang salah. Seperti penggunaan lampu, penggunaan starter untuk lampu TL, dan pemasangan saklar yang kurang baik. Siswa dapat memeriksa masalah tersebut dan mencari solusinya.

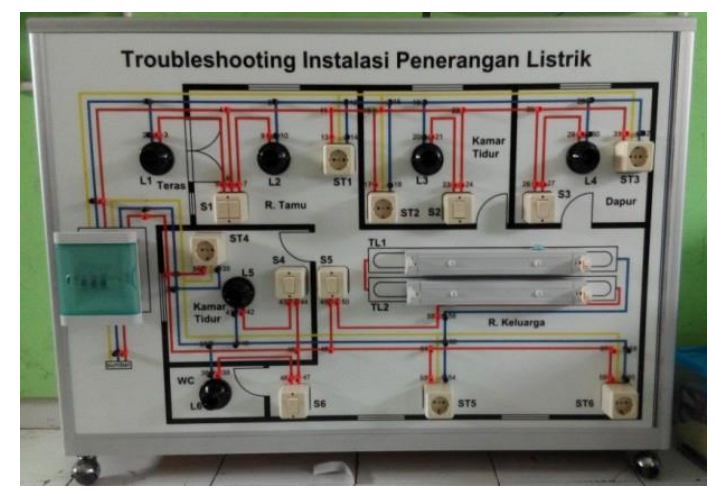

(a)

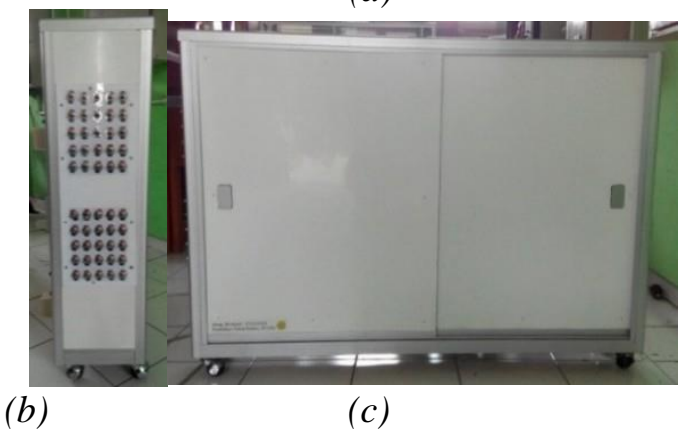

Gambar 2. (a) Tampak Depan, (b) Tampak Samping, (c) Tampak Belakang Hasil Produk Trainer

Merancang trainer dimulai dari membuat gambar denah rumah beserta pengawatan instalasi penerangan listrik menggunakan aplikasi AutoCad 2010. Selanjutnya gambar tersebut dicetak/print out pada bahan stiker transparan dan ditempelkan diatas permukaan papan akrilik. Papan akrilik yang sudah ditempel gambar tersebut akan menjadi tampilan depan dari trainer.

Perancangan badan alat diserahkan kepada jasa pembuatan etalase dengan bentuk dan ukuran yang dikehendaki sesuai perencanaan. 
Badan trainer yang telah jadi selanjutnya dipasangkan komponen-komponen listrik. Selanjutnya dipasang juga rangkaian sambungan kabel penghantar di dalam badan trainer.

Pada umumnya, alat yang digunakan sebagai media pembelajaranharus memiliki prosedur penggunaan atau pemakaian yang jelas agar dapat digunakan sesuai dengan cara kerja dan kebutuhannya. Begitu pula dengan Trainer Troubleshooting Instalasi Penerangan Listrik yang memiliki prosedur penggunaan sebagai berikut:

1. Trainer Troubleshooting Instalasi Penerangan Listrik menggunakan sumber tegangan $220 \mathrm{~V}$ dari jala-jala PLN.

2. Sistem instalasi penerangan listrik pada trainer tersebut akan bekerja dengan normal jika sakelar simulasi yang di samping badan trainer dalam kondisi ON atau tersambung dan jumlah beban yang digunakan disetiap komponen listrik tidak melebihi kapasitas beban pada pengaman arus yang terpasang.

3. Mensimulasikan kegagalan sistem instalasi penerangan listrik terhadap sambungan atau kawat penghantar dapat dilakukan dengan mengubah kondisi sakelar simulasi yang awalnya ON menjadi OFF atau terputus. Pemutusan sakelar simulasi (keadaan OFF) dapat dilakukan sesuai lembar kerja/jobsheet. Sakelar simulasi yang terputus tersebut menyebabkan salah satu atau lebih komponen listrik tidak berfungsi, sehingga dapat dilakukan pemeriksaan pada jalur pengawatan melalui banana jack yang telah terpasang menggunakan alat ukur ohmmeter dan voltmeter.

4. Pengujian menggunakan ohmmeter dilakukan dengan kondisi sistem instalasi penerangan listrik yang tidak teraliri arus listrik (nonaktifkan MCB), sedangkan pengujian dengan voltmeter harus dalam keadaan teraliri arus listrik. Pengujian melalui banana jack mengikuti langkah kerja pada lembar kerja/jobsheet. Selanjutnya, jika sudah menentukan sambungan penghantar yang terputus maka perlu disambung dengan kabel penghantar agar sistem normal kembali melalui banana jack.

5. Mensimulasikan gangguan beban lebih pada sistem instalasi penerangan listrik dapat dilakukan dengan memberikan beban pada setiap komponen listrik dengan memperhatikan perhitungan beban terpakai dengan kapasitas beban pada pengaman arus yang terpasang.

6. Mensimulasikan gangguan komponen peralatan listrik dapat dilakukan dengan memberikan komponen listrik yang rusak.

\section{Tes/Uji Coba}

Hasil pengujian trainer tanpa tegangan terhadap fungsi kerja sambungan rangkaian dari kawat penghantar menggunakan ohmmeter menunjukkan bahwa setiap jalur sambungan pengawatan penghantar fasa atau penghantar netral, baik pada pengawatan instalasi kelompok 1 atau kelompok 2, yaitu terhubung atau tersambung. Sedangkan untuk jalur sambungan pengawatan penghantar fasa dengan penghantar netral, baik pada pengawatan instalasi kelompok 1 atau kelompok 2, yaitu tidak terhubung atau terputus. Dengan demikian hasil pengujian terhadap sambungan rangkaian kawat penghantar sudah sesuai dengan perencanaan desain pengawatan instalasi listrik dan peletakkan banana jack.

Sedangkan hasil pengujian trainer dengan tegangan terhadap fungsi kerja sakelar simulasi yang ada di samping badan trainer menunjukkan bahwa setiap sakelar simulasi dapat mempengaruhi fungsi setiap komponen listrik. Fungsi kerja seluruh sakelar simulasi berdasarkan desain perencanaan peletakan sakelar simulasi gangguan sudah sesuai. Selain itu, pengujian terhadap beban lebih dengan memasangkan lampu dan peralatan listrik pada komponen listrik dalam trainer dengan memperkirakan beban yang terpakai melebihi kapasitas beban pengaman arus yang terpasang sehingga menyebabkan MCB menjadi trip atau turun sudah sesuai dengan perencanaan perhitungan.

Pengujian juga dilakukan dan dinilai oleh ahli media pembelajaran, ahli materi bidang bersangkutan, dan pengguna alat tersebut, yaitu guru dan siswa untuk mengetahui tingkat kelayakan sebagai media pembelajaran dengan menggunakan instrumen penelitian berupa angket. Sebelum instrumen penelitian digunakan, instrumen melewati uji validitas oleh ahli instrumen agar instrumen dapat layak digunakan. 
Instrumen yang diberikan pada ahli materi digunakan untuk mengetahui tingkat validasi isi (Content Validity), sedangkan yang diberikan pada ahli media pembelajaran untuk mengetahui tingkat validasi konstrak (Construct Validity).

Hasil uji validasi media pembelajaran berupa Trainer Troubleshooting Instalasi Penerangan Listrik yaitu sebagai berikut:

\section{Validasi isi (Content Validity)}

Tingkat validasi isi diperoleh dari hasil penilaian ahli materi pembelajaran instalasi penerangan listrik oleh Bapak Drs. Irzan Zakir, M.Pd, dosen Program Studi Pendidikan Teknik Elektro UNJ, ditinjau dari aspek materi dengan indikator meliputi kesesuaian, kelengkapan, kualitas materi, dan kemanfaatan terhadap Trainer Troubleshooting Instalasi Penerangan Listrik mendapat persentase $72 \%$, sehingga tingkat validasi isi dari Trainer Troubleshooting Instalasi Penerangan Listrik sebagai media pembelajaran Instalasi Penerangan Listrik kelas IX adalah sesuai sehingga layak digunakan.

2. Validasi konstrak (Construct Validity)

Tingkat validasi konstrak diperoleh dari hasil penilaian ahli media pembelajaran oleh Bapak Dr. Moch. Sukardjo, M.Pd., dosen Jurusan Teknik Elektro UNJ, ditinjau dari aspek teknis dengan indikator meliputi tingkat keamanan, kualitas trainer, kemudahan pengguna, dan kemanfaatan terhadap Trainer Troubleshooting Instalasi Penerangan Listrik mendapatkan persentase $84,7 \%$, sedangkan ditinjau dari aspek tampilan dengan indikator meliputi konstruksi media, keserasian dan kerapian terhadap trainermendapatkan persentase sebesar $100 \%$. Sehingga dari keseluruhan aspek yang dinilai oleh ahli media pembelajaran diperoleh persentase ratarata sebesar 89,6 \%. Dengan demikian, validasi konstrak dari Trainer Troubleshooting Instalasi Penerangan Listrik sebagai media pembelajaran Instalasi Penerangan Listrik kelas IX adalah sangat sesuai dan layak digunakan.

3. Validasi ujicoba pemakaian

Tingkat validasi yang diperoleh dari hasil uji pemakaian oleh 30 siswa kelas XI TL-1 SMKN 5 Jakarta dan dua guru mata pelajaran
Instalasi Penerangan Listrik kelas XI, ditinjau dari aspek teknis dengan indikator meliputi tingkat keamanan, kualitas trainer, kemudahan pengguna, kesesuaian materi, membantu proses pembelajaran, dan meningkatkan motivasi mendapat persentasi sebesar 82,21\% untuk murid dan 93,89\% untuk guru, sedangkan ditinjau dari aspek tampilan dengan indikator meliputi bentuk dan ukuran media, keserasian, dan kerapian mendapat persentasi sebesar 82,67\% untuk murid dan $91,42 \%$ untuk guru. Sehingga dari keseluruhan aspek yang dinilai oleh siswa diperoleh persentase rata-rata sebesar 82,32 $\%$, sedangkan oleh guru diperoleh 93,2 \% . Dengan demikian, tingkat validasi trainer Troubleshooting Instalasi Penerangan Listrik sebagai media pembelajaran Instalasi Penerangan Listrik kelas IX adalah sangat sesuai dan layak digunakan.

\section{KESIMPULAN DAN SARAN \\ Kesimpulan}

Berdasarkan hasil penelitian dan pembahasan yang telah diuraikan, maka dapat ditarik kesimpulan sebagai berikut:

1. Trainermemiliki bentuk bangun ruang balok dengan ukuran panjang $120 \mathrm{~cm}$, lebar $25 \mathrm{~cm}$, dan tinggi $80 \mathrm{~cm}$ dengan tampilan depan trainer menunjukkan gambar denah bangunan rumah sederhana lengkap dengan pengawatan instalasi penerangan listriknya. Trainer dirancang dengan memiliki tiga bentuk gangguan instalasi penerangan listrik yang dapat disimulasikan, diantaranya: (1) gangguan pada sambungan penghantar/kabel instalasi listrik, (2) gangguan beban lebih dan (3) gangguan pada komponen peralatan listrik yang salah.

2. Perancangan trainer dimulai dari membuat gambar denah rumah beserta pengawatan instalasi penerangan listrik menggunakan aplikasi AutoCad 2010 yang selanjutnya dicetak/print out pada bahan stiker transparan dan ditempelkan diatas permukaan papan akrilik. Perancangan badan alat diserahkan kepada jasa pembuatan etalase dengan bentuk dan ukuran yang dikehendaki sesuai perencanaan. Badan trainer yang telah jadi selanjutnya dipasangkan komponen- 
komponen listrik dan dipasang juga rangkaian sambungan kabel penghantar di dalam badan trainer.

3. Penggunaan trainer dapat dilakukan dengan cara: (1) Trainer Troubleshooting Instalasi Listrik dapat bekerja apabila steker/tusuk kontak yang di belakang trainer disambungkan pada sumber listrik PLN tegangan AV 220V (2) Simulasi gangguan sambungan pengawatan instalasi penerangan listrik dapat dilakukan dengan mengubah kondisi sakelar simulasi yang ada di samping badan alat. (3) Pemeriksaan sambungan penghantar menggunakan alat ukur ohmmeter dan avometer dapat dilakukan pada banana jack. (4) Simulasi beban lebih dapat dilakukan dengan memasangkan peralatan listrik dengan jumlah beban melebihi $450 \mathrm{~W}$ seperti setrika listrik, hairdryer, dll pada stop kontak dalam trainer. (5) Simulasi gangguan komponen listrik dapat dilakukan dengan memberikan peralatan listrik yang sudah rusak. (6) Pelaksanaan praktikum menggunakan trainer Troubleshooting Instalasi Listrik mengikuti langkah kerja pada lembar kerja/jobsheet.

4. Tingkat kelayakan Trainer Troubleshooting Instalasi Penerangan Listrik sebagai media pembelajaran pada mata pelajaran Instalasi Penerangan Listrik kelas XI di SMKN 5 Jakarta didapatkan dari data instrument penelitian oleh tiga kelompok penilai, diantaranya: (1) Ahli materi, menilai trainer dari aspek materi dengan skor yang didapatkan sebesar $72 \%$ sehingga dinyatakan sesuai, (2) Ahli media, menilai trainer dari aspek teknis dan tampilan dengan perolehan skor sebesar 89,6 \% sehingga dinyatakan sangat sesuai, dan (3) Pengguna, meliputi 2 guru dan 30 siswa yang menilai dari aspek teknis dan tampilan memperoleh skor sebesar 93,2 \% untuk guru dan 82,32\% untuk murid, sehingga dinyatakan sangat sesuai. Dengan demikian, hasil uji kelayakan terhadap Trainer Troubleshooting Instalasi Penerangan Listrik yaitu layak digunakan sebagai media pembelajaran pada mata pelajaran Instalasi Penerangan Listrik kelas XI di SMKN 5 Jakarta.

\section{Saran}

Berdasarkan keterbatasan alat yang telah disebutkan, maka untuk pengembangan alat trainer selanjutnya perlu diperhatikan kembali dalam pemasangan roda dibagian bawah trainer sehingga tidak mudah jatuh dan bergeser-geser saat digunakan, dan juga perlu ditambahkan kabel penghantar ground dalam pengawatan instalasi penerangan listrik tersebut sehingga penggunaan trainer akan lebih aman lagi, serta kabel yang digunakan seharusnya menggunakan kabel jenis NYA agar sangat sesuai dengan PUIL.

\section{DAFTAR PUSTAKA}

Anggraini, Dewi. 2016. Pembuatan Trainer Instalasi LIstrik sebagai Media Pembelajaran untuk Mata Kuliah Teknik Instalasi Listrik [skripsi]. Jakarta: Fakultas Teknik, Universitas Negeri Jakarta.

Arikunto, Suharsimi. 2012. Dasar-dasar Evalusai Pendidikan. Jakarta: Bumi Aksara.

Arikunto, Suharsimi. 2013. Manajemen Penelitian. Jakarta: Rineka Cipta.

Departemen Pendidikan Nasional. (2008). Kamus Besar Bahasa Indonesia. Ed ke-4. Jakarta: PT Gramedia Pustaka Utama.

Departemen Pendidikan Nasional. (2008). Undang-Undang SISDIKNAS (Sistem Pendidikan Nasional) UU RI No. 20 Th. 2003. Jakarta: Sinar Grafika.

Fathkhurozi, Setio. 2012. Trainer Pesawat Penerima Radio AM/FM sebagai Media Pembelajaran untuk Kelas XI Teknik Audio Video di SMK $N \quad 3 \quad$ Yogyakarta [skripsi].Yogyakarta: FT UNY.

Nasution. 2002. Metode research (Penelitian Ilmiah). Jakarta: Bumi Aksara.

Sadiman, Arief S. 2008. Media Pendidikan Pengertian, Pengembangan, dan Pemanfaatannya. Jakarta: PT RajaGrafindo Persada. 
Sugiyono. 2009. Metode Penelitian Kuantitatif, Kualitatif, dan R\&D. Bandung: Alfabeta.

Sukardi. 2008. Evaluasi Pendidikan Prinsip \& Operasionalnya. Jakarta: Bumi Aksara.

Wena, Made. 2009. Strategi Pembelajaran Inovatif Kontemporer: Suatu Tinjauan Konseptual Operasiona. Jakarta: Bumi Aksara. 